\title{
Strategic Vision into Operational Reality: A Case Study on Menga Berhad's Transformation Journey
}

\author{
Patricia Francis, Dileep Kumar M \\ Othman Yeop Abdullah Graduate School of Business, Universiti Utara Malaysia \\ patriciafrancis11@yahoo.com
}

\begin{abstract}
This case study describes the problems faced and transformation efforts taken by the Board of Directors of Menga Berhad in order to stay relevant in the evolving requirements of technology in the ICT industry. The case was identified as a result of stiff competition faced by Menga over the years which resulted in declining of revenues and profit margins, delayed projects and declining customer satisfaction during the recent years and how the strategic vision was turned into operational reality. The data related to the case study has been compiled from Company's Periodic Financial Statements, BURSA announcements given by the new management, websites, articles and through interviews and discussions with the relevant stakeholders of Menga Berhad. The analysis is based on management theories and proven concepts. The strategic intervention identified is per that which has been undertaken by the management in order to mitigate the issues that were being experienced by Menga Berhad. The outcomes of those strategic interventions along with the outcomes, justification of managerial decision making and its critical analysis have been recorded in order to provide further insights to the readers for future application.
\end{abstract}

Keywords: Strategic Management, Operations, financial performance, ICT

\section{Introduction}

Menga Berhad has been one of Malaysia's leading ICT solutions provider and a renowned forte for more than 30 years as a result of focused business efforts, professionalism, cutting-edge technology and innovativeness. Menga started out as a company selling BIM office products in 1981 but has now evolved into a multiplatform business solutions provider with a paid-up capital of RM60.4m and a company listed on Bursa Securities (Main Market) since 1999. Menga has its Headquarters in Subang Jaya, branch offices in Penang and Johor Bahru and 41 nationwide service locations. However, the evolving requirements of technology, emerging new companies in the ICT arena and the current economic down turn have caused the profitability of Menga to decline significantly over the years. With the declining trend in its revenue and dwindling down of profit margins, the Board of Directors decided that it was time for the major shareholder of the company and the son of the late founder of Menga Berhad, En. Phil Sulaiman, to step in the operations of the company in 2008. Thus, began the transformation journey of Menga Berhad with Phil as the Managing Director, (MD). Phil, as the new MD, is supposed to steer Menga towards offering business solutions that would directly impact customer profitability and value, away from Menga's traditional role as a technology provider. However, after joining as the MD, Phil realised that besides the stiff competition and declining profits, Menga was also having other major problems such as poor monitoring at operational level, delayed projects, talent attrition, ineffective cost management and declining customer satisfaction during the recent years. Phil strongly believed that an ultimate change in Menga's approach in which it relates to its customers was utmost necessary in order to stay relevant in the current evolving technology industry as to negate the chances of further reduction in its profitability margins and stiff competition. However, after serving 6 years as the MD, Phil stepped down on 31 December 2013 to allow Mofit Abdullah to take on the role of the MD starting 1 January 2014 to continue the $2^{\text {nd }}$ phase of the transformation journey of Menga Berhad.

Profile of Company: Menga was established in 17 December 1981 at a time when the country's IT industry was still in its infancy. The establishment was in response to Malaysia's New Economic Policy (NEP) to increase Bumiputera participation in the technology industry. A strategic plan was developed to cultivate local entrepreneurial talent by utilizing a pool of ready talents in BIM and incorporating a company that would serve as BIM's sole hardware dealer and agent in Malaysia in order to penetrate into the local market. 
The team was headed by the late Ismail Sulaiman, who was formerly the General Manager of BIM Malaysia. Together with a team of about 50 senior BIM personnel, Menga became fully operational on 1 January 1982 with a paid-up capital of RM500,000. Though it started out as a company selling BIM office products, it has now evolved into a multi-platform business solutions provider with a paid-up capital of RM60.4 million.

The vision of Menga is to be, "The Malaysian IT partner of choice." For its customers, Menga desires to be the primary reference point for its customers' IT needs. It also acknowledges that it can only be achieved by a perfect alignment of its goals with those of its customers. It involves deeply understanding how customers create business value and deploying technology in its attainment. Menga has made its mission to help customers succeed. In order to fulfill the Mission, it is imperative that the company understand their environment and challenges. While it will continue to leverage on its strong partnerships with globally renowned partners to provide customers with innovative technology, Menga views technology merely as an enabler in improving business performance. Menga's main aim is to enhance its value proposition by maximizing the returns on their IT investments. Menga structure is divided into two main areas; business divisions and support divisions. Business divisions comprise Maintenance \& Managed Services, Project Management, Solution Marketing, Hardware Infrastructure, Network Services Unit, Partner Management, Software Infrastructure, Sales, Solutions Integration, Shared Services \& Outsourcing and Software Development. Support divisions comprise Finance, Internal Audits, Business Control, Legal, Human Resources, Corporate Communications, Information Systems, General Services and Sales Support. Menga Berhad, is also the holding company of the following subsidiaries:

- Menga Services Sdn. Bhd. (Provision of maintenance and managed services)

- Menga Alliances Sdn. Bhd. (Provision of strategic IT outsourcing business) Menga MSC Sdn. Bhd. (Provision of solution services and technology, research and development)

- Menga SSO Sdn. Bhd. (Under members' voluntary winding-up)

- Menga Techniques Sdn. Bhd. (Under members' voluntary winding-up)

- VA Dynamic Sdn. Bhd. (Sale of networking cables and related products)

\section{Problem}

Being a company that was formed as a BIM arm or agent to penetrate into the local market in Malaysia, Menga found itself only dealing with sole hardware in its initial years. However, over the years, it realized that it needed to diversify itself into other business areas with the slow decrease in its hardware sales due to evolution in technology that was moving away from the need of having hardware with the introduction of internet, shared data centre and cloud services. Within the last 30 years, the technology landscape has changed tremendously. New trends have emerged resulting in a sea of change in the way companies do business. Across the board, companies these days are constantly on the lookout for solutions that will give them an edge over their competition. As such, Menga is constantly striving for ways to provide customers with an experience that will allow them to achieve their business objectives. However, over the years, Phil felt that there was a need to venture into other more value-added services outside the hardware and maintenance business into areas such as solution marketing, network services, software infrastructure, solutions integration, concept proposal, shared Services \& outsourcing and software development.

Along with the need to diversify, Menga also found the need to work with other technology partners such as Microsoft, Cisco, Juniper, HP, Lenovo, Oracle, Hitachi and other local and international partners depending on the needs and appetite of the customers. In addition to that, the Board felt that a transformation was necessary because increasingly customers wanted more for less and Menga was unable to concede further. The market had commoditised and from an exclusive ICT company, Menga found itself to become one of the players in the field, turning us into a 'we also can do' company with nothing exclusive to offer. Menga needed to regain its exclusivity once again and become an 'only we can do' company. As the Managing Director, Phil resorted to take immediate actions in order to save Menga from dwindling profits. Besides the dwindling profits, there were other operational issues that needed to be sorted out as well, such as poor monitoring at operational level, delayed projects, talent attrition or lack of capability amongst the staff and ineffective cost management. These operational issues in evidently affected the quality of projects carried out and directly affected customer satisfaction over the recent years. The lack of assurance in all areas of operations also 
resulted in decrease in productivity. Therefore, Phil felt that he needed to find the causes of the problems which he believed was highly related to the loose top level leadership and lack of monitoring. Amongst the management concerns that were identified were that there were leakages in the cost which are irrelevant to the projects. The dwindling profits is clearly demonstrated when a comparison is done between the Condensed Consolidated Statement of Comprehensive Income for the $3^{\text {rd }}$ Quarter ended 30 September 2013 and 30 September 2010, where there was a significant decrease in revenue and profit amounting to more than RM1.5m and RM3.5m respectively. Delayed or untimely project delivery was a result of poorly managed projects. The poorly managed projects and extended timeline of project delivery also impacted the pricing of projects, hence, projects that were carried out resulted in project losses instead of profits due to there being cost overrun in most of the projects that were undertaken as there needed to be rectification steps taken to improve the quality of the projects before it was delivered to the customers.

Phil also identified potential risks both internal and externally. Internally, he identified there to be talent attrition as more and more employees looked for better paying options outside Menga, where Menga found itself not able to match those better offers due to the declining profit. It has been a very painful experience for Phil because Menga acknowledges that the employees are the lifeblood of its business and believes in attracting the best talent, enabling them to exploit their full potential, deploying them to greatest benefit and meriting their continued service and commitment. Menga recognises that success in meeting employee goals is a precondition to meeting organisation goals. It was also a tough journey for Phil because the ability to penetrate into new markets was hindered by timing issue where new investment may not be able to yield immediate returns to cover costs. On the other hand, the potential risks externally such as the drop in public sector and Government Linked Companies spending in 2014 as those sectors needed to beef up after the elections. Besides that, the macroeconomic condition such as the potential implementation of Goods Services Tax (GST) did not help the current problematic situation of Menga. In addition to that, those problems and issues identified also resulted in declining organizational culture and enthusiasm which impacted the working morale and increased level of absenteeism. Employees started performing personal tasks during office hours due to lack of accountability and poor job satisfaction. This also resulted in managers and staff working without having any objective or targets due to lack of commitment. This also resulted in poor knowledge management, skills depletion and lack of innovation culture in the entire organization. All in all, the entire scenario resulted in the loss of credibility, poor competitive advantage and failing company image amongst customers. Fundamentally, it seemed like a collapsing giant and if immediate attention is not given, ultimately it would result in the downfall of Menga Berhad.

\section{Strategic Interventions}

Business performance of a company is a top priority for its corporate leaders. Without sustainable performance the long term viability of a company is at risk. Business performance is determined by subjective self-reporting measures via structured questionnaire, where the firms would be asked to assess their financial and market performances relative to key competitors. Measurement will be based on the overall perceived business performance and sales growth. The study done by Chow (2006) concluded that business performance is closely linked to the organizational characteristics, such as ownership (state owned vs. non-state owned) and the size of the firm. Non-state enterprises that were established in the recent years remained small and that ownership types, firm size, firm age, and business environment are all negatively associated with profitability. In a strategy to address the above mentioned problems, Phil changed the Company mission to 'Driving Customer Success'. Menga was offering technology, but what customers really wanted was success. Hence, it chose to graduate from offering customers technology, to offering them success through technology. Success to customers means lower operating costs, better output, and lower risk, which are the drivers of value and the purpose of technology in business. Hambrick and Fredrickson, (2001) defines strategy as a central, integrated concept on how an organization would achieve its objective. Menga's new strategy was aimed at improving its margins via strategic management. Strategic management traditionally focuses on business concepts that affect the performance of an organisation (Hoskisson et al., 1999). Phil looked into areas that can be accomplished through technology, rather than just demand for the technology itself. With that, a Concept Proposal unit was established which drove a sales agenda that promoted value creation for customers and formed 20\% of Menga's business with improved margins. Menga was building more profound customer relationships that affect all business it does with its customers. 
Phil also drove to develop home-grown solutions to drive customer success, where Menga ventured into ICC solution to promote a complete living experience for residents of real estate developments while next solutions will likely involve mobility where our people have designed creative offerings that drive customer success. For our new technology bets, Phil favoured those that allow differentiation and value creation, such as Analytics and Mobility. In the traditional technology areas, Menga was driving innovation through their Productisation initiative which involved the differentiation of its engineers where it looked into increasing the solution. Menga engaged with partners in the vertical industry and developed functional solutions in an attempt to offset the impact of cloud on our traditional business and buy time in developing a viable cloud strategy. Phil also moved Menga from principal alignment to customer alignment, where customer interest was key. He believed that if Menga becomes precious to customers, the principals will come to us. To help itself into breaking free from a principal alignment, it signed up more principals and endured the discomfort. Nwokah (2008) defined marketing orientation as a concept that holds the key to achieving organisational goals such as market shares, sales growth and profitability. The study which was conducted in Nigeria also pointed that a market-oriented organization is presumed to have superior market-sensing and customerlinking capabilities, and these capabilities are presumed to assure them higher profits in comparison with organizations that are less market-oriented. Market orientation has emerged as a significant antecedent of performance and is presumed to contribute to long-term success. Phil also grew the Telco and enterprise business dramatically to form $70 \%$ of Menga's book as it struggled with cutbacks in public spending over the last 2 years which could have been worse without all the above mentioned strategies. These new segments exposed Menga to open market competition and allowed itself to increase its capabilities and competitiveness. Menga saw its business evolving from infrastructures to services.

Besides value creation, Menga also chose to create the best customer experience and improve its operational effectiveness. Although improvement in operations, which is simply doing the same things in a better way doesn't amount to a strategy, it does improve performance of an organization. Though it developed multiple initiatives and expended much effort, Phil felt that Menga has been inadequately successful. Customers complained of poor coordination and its operational costs were excessive. Phil's lack of experience in operations did not help to improve the situation that was being faced by Menga. Hence, in May 2013, Phil resorted to bring a previous customer of Menga, Gohwee See Wee as the Chief Operating Officer in an attempt to help rectify the operational issues and increase the financial performance of Menga. Phil welcomed Gohwee into the Menga family with much anticipation. Gohwee was previously from SCB, a long standing Menga customer, who has held various leadership positions within various SCB IT functions. Gohwee was to be responsible for driving Operational Excellence and Effectiveness, as well as managing the change initiatives that were put in place. Besides the recruitment of Gohwee, there was initially no change to the existing leadership structure. The coming on board of Gohwee created a dramatic impact on Menga Berhad. Phil dared to say that he was learning new things and was excited by Gohwee's perspective. Gohwee was driving improved operational effectiveness and customer experience. Menga was being moved from a fulfilment service to a delivery business, one which strives for relevance and performance.

After almost 6 years as the Managing Director of Menga Berhad, Phil decided that it's time he made way for a new Managing Director to complete the transformation journey that was started in 2008, as he felt that he has acquired a better understanding of my strengths and my limitations. As an Accountant by qualification, he felt that he had good ideas and strategies but realised that more could have been accomplished with better management skills and a deeper understanding of ICT operations. Phil felt that Menga needed someone who can inject new energy and do justice to the foundation that has been built. Mofit Abdullah was brought on board as the $4^{\text {th }}$ Managing Director of Menga Berhad, starting 1 January 2014. Mofit has had 25 years of experience in the ICT industry includes leading HP's consulting and SI businesses, and the Maxis enterprise business. Mofit's appointment comes as the right time as Menga attempts to drive a higher margin business by offering more strategic and outcome-centric business solutions and services to its customers. Along with Gohwee, the COO, Mofit is expected to drive and deliver the success that was sought within the next few years. Together, they are supposed to expand Mengas horizon and offer the group of companies an exciting and fulfilling journey. 
Outcomes of each Intervention: Besides all the previous transformation efforts taken by Phil since 2008, the appointment of both Mofit and Gohwee has resulted in the following interventions in order to further turn around the profitability of the company:

- 2014 Menga Group Business Plan and Budget

- 2014 Delivery Structure

- Formation of Commercial Control Unit

Intervention 1 - 2014 Menga Group Business Plan and Budget: In order to achieve the targets set for 2014, the following solutions have been identified to overcome the problem which is to strengthen the top leadership layer, intensify monitoring for better controls over operations. In addition to that, there needs to be a reevaluation of foreign opportunities where such opportunities are led by customers themselves. Menga brand also needs to be further strengthened in order to attract top talent. The management also has pointed that there need to be more discipline applied in cost management in order to increase the profit despite the declining revenue to the stiff competition. Besides all those, the management has also formulated the strategy to deliver high quality customer experience in order to grow wallet share. As the change has only been currently been enforced, the outcome of these interventions is still under detailed scrutiny. However, there has been some cost savings over the span of the last 2-3 months since Gohwee's intervention into the operations of Menga.

Intervention 2 - 2014 Delivery Structure: Besides setting up a target for 2014, there was also a business process re-engineering of the Menga delivery structure in order to tighten up loose ends in terms of proper execution and delivery of projects. There was a need for a redefinition of the middle management requirement and deliverables in order to improve the profitability of the company. The immediate result of having such a re-engineering in the delivery structure has led to better visibility of the cost and profitability of each project undertaken. Thus improving the performance of these delivery departments and in turn, the overall company performance would surely be impacted.

Intervention 3 - Formation of Commercial Control Unit: The Commercial Control Unit was formed to track overall business performance against agreed target (GP) across all business lines, ensure that all existing businesses are profitable ensure that all projects are delivered on time and on budget, manage all project risks and ensure discipline of good project governance via the following functions:

- $\quad$ Business Analysis \& Control

- $\quad$ Risk Management (Delivery)

- $\quad$ Project Analysis

Justification of Managerial Decision Making and Critical Analysis: Below is the critical analysis performed in justification of the managerial decisions that were undertaken during the entire course of transformation of Menga Berhad:

\begin{tabular}{|c|c|c|}
\hline Problem & Management Intervention & Critical Analysis \\
\hline $\begin{array}{l}\text { Dwindling down of } \\
\text { financial performance }\end{array}$ & Business Succession Planning & $\begin{array}{l}\text { With the change in time, it is essential for } \\
\text { companies that are family owned to look } \\
\text { into its successors for continuous growth } \\
\text { of the business in changing times. }\end{array}$ \\
\hline $\begin{array}{l}\text { Ineffective monitoring at } \\
\text { operations level and lack } \\
\text { industry experience }\end{array}$ & Change in top management & $\begin{array}{l}\text { The top management has direct impact } \\
\text { on the performance of the any } \\
\text { organization as the styles of each leader } \\
\text { vary according to their respective } \\
\text { exposure and experience. }\end{array}$ \\
\hline $\begin{array}{l}\text { Delayed } \\
\text { projects }\end{array}$ & $\begin{array}{l}\text { Intensify monitoring and } \\
\text { redefinition of middle } \\
\text { management requirement and } \\
\text { deliverables }\end{array}$ & $\begin{array}{l}\text { Employees of company require } \\
\text { continuous monitoring and supervision } \\
\text { in order to ensure continued } \\
\text { performance of the organizations. }\end{array}$ \\
\hline Talent attrition & $\begin{array}{l}\text { Strengthen the brand offer } \\
\text { especially to attract top talent }\end{array}$ & $\begin{array}{l}\text { In order to further improve the } \\
\text { profitability, there is a need for the }\end{array}$ \\
\hline
\end{tabular}




$\begin{array}{lcl}\begin{array}{l}\text { Ineffective } \\ \text { management }\end{array} & \text { cost } & \begin{array}{l}\text { Be very disciplined in cost } \\ \text { management }\end{array}\end{array}$

Dwindling down of Deliver high quality customer customer experience experience (to grow wallet share)

No intervention into Evaluate foreign opportunities foreign market due to total where such opportunities are concentration on local led by customers entrance of new breed and more techno savy generation into the company in order to change the culture of the organization.

For sustainable performance and improvement, KPI's (Key Performance Indicators) are necessary to guide the departments towards performance.

As in any business, customers are the lifeblood of the organization. Hence, with improved customer experience, there will be a definite increase in profitability.

Potential increase in market share with there being income from foreign opportunities.

market

\section{Conclusion}

The financial performance or the gross profit of a company is an important indicator that shows if a company is going in the right or planned direction in any industry. As studied in the case, the financial performance was used as a main indicator to measure the growth of Menga Berhad in the in the ICT industry and also as a target to maneuver the company back to its rightful direction by the management transformation that was undertaken by the Board of Directors and its major shareholder. Along with all the measures that have been taken since 2008 such as the appointment of Phil, the new appointment of Mofit and also the 2014 financial target that has been set by the new management to reposition the company back on track, it is certain that a bright future awaits Menga Berhad in the ICT industry. The new management intends to see a surplus in the profit of the company in 2014, as planned. Gohwee the Chief Operating Officer is certain that amongst the main problem of the dwindling profits in Menga was due to lack of monitoring of operations, poor cost control and performance of departments within the organization. A total transformation driven by the Board of Directors was necessary to make sure that the profitability of Menga Berhad would increase again. The other reason is that the shareholders of Menga have been waiting for a couple of years to obtain fruitful dividends as in the past before the revenue and profitability started dwindling down.

\section{Reference}

Chow, I. H. (2006). The relationship between entrepreneurial orientation and firm performance in China. Sam Advanced Management Journal, 3, 11-20.

Digital News Asia. (2013). December 16). Ex-Maxis senior VP Mofit takes over the helm at Menga. Retrieved from http://www.Menga.com.my/downloads/press/ Digital\% 20News \%20Asia\%20ExMaxis\%20senior\%20VP\%20Mofit\%20takes\%20over\%20the\%20helm\%20at\% 20Menga.pdf

Gohwee, S. W. (2013). Personal communication, MengaComms2U 21122013.ppt, (2013, December 17)

Hambrick, D. C. \& Fredrickson, J. W. (2001). Are you sure you have a strategy? Academy of Management Executive, 15(4), 48-59.

Home Business. (2007). Phil is Menga's new MD. The Edge Financial Daily. Retrieved from http://www.Menga.com.my/downloads/news/2007/Phil_is_Menga_new_MD.pdf

Hoskisson, R., Hitt, M., Wan, W. \& Yiu, D. (1999). Theory and research in strategic management: swings of a pendulum. Journal of Management, 25(3), 417-456.

Jimmy, Y. (2006). Menga unveils biz transformation process to sustain growth. The Edge Daily. Retrieved from http://www.Menga.com.my/downloads/news/2006/ Mengaunveils_ biz_transformation_procss_to_sustain_growth.pdf. www.theedgedaily.com.

Mengawebsite. (2014). http://www.Menga.com.my/investor.html (Assessed on 29/1/ 2014) 
Nadia, S. H. (2011). Menga's new strategy starting to bear fruit. The Edge Malaysia Business and Investment Weekly. Retrieved from http://www.Menga.com.my/ downloads/news/2011/Phil\%20The\%20Edge.pdf

Nwokah, N. G. (2008). Strategic market orientation and business performance: The study of food and beverages organisations in Nigeria. European Journal of Marketing, 42(3/4), 279-286.

Zatil, H. (2013). Business \& Markets 2013. The Edge Malaysia. Retrieved from http://www.Menga.com.my/downloads/press/The\%20Edge\%20Financial\%20Daily\%20

Menga\%20appoints\%20new\%20MD\%20starting\%20Jan\%202014.pdf

Appendix 1 - Condensed Consolidated Statement of Comprehensive Income for the $3^{\text {rd }}$ Quarter ended 30 September $2013 \& 3^{\text {rd }}$ Quarter ended 30 September 2011

\begin{tabular}{|c|c|c|c|c|}
\hline & 2013 & 2012 & 2013 & 2012 \\
\hline & $\begin{array}{c}\text { CURRENT } \\
\text { Qtr ended } \\
30 \text {-Sep } \\
\text { (RM ODO) }\end{array}$ & $\begin{array}{c}\text { Comparaitive } \\
\text { Ott ended } \\
\text { 30-Sep } \\
\text { (RN CoOD) }\end{array}$ & $\begin{array}{c}9 \text { 9onith } \\
\text { Cumulative } \\
\text { to-date } \\
\text { (RM 'OCO) }\end{array}$ & $\begin{array}{l}9 \text { Month } \\
\text { Cunnuative } \\
\text { to-vate } \\
\text { (RM 1000) }\end{array}$ \\
\hline Revenue & 75,219 & 97,524 & 211,795 & 233,477 \\
\hline Operating expenses & $(71,305)$ & $(93,132)$ & $(200,788)$ & $(220,180)$ \\
\hline Depreclation & $(1,852)$ & $(1,738)$ & $(5,587)$ & $(5,091)$ \\
\hline Other operailing Income & 416 & 439 & 798 & 1,242 \\
\hline Profit from operations & 2,478 & 3,093 & 6,218 & 9,448 \\
\hline Finance costs & (342) & (300) & $(1,044)$ & $(427)$ \\
\hline Profit before tax & 2,136 & 2,793 & 5,174 & 9,021 \\
\hline Taxatilon and Zakatt & (757) & $(1,018)$ & $(1,577)$ & $(2,886)$ \\
\hline Profit ater tax & 1,379 & 1,775 & 3,597 & 6,135 \\
\hline Other Comprenensive Income & - & - & - & $\cdot$ \\
\hline Total Comprenentive Income & 1,379 & 1,775 & 3,597 & 6,135 \\
\hline \multicolumn{5}{|l|}{ Profit attifloutable to: } \\
\hline - Equlty holders of the company & 956 & 1,320 & 2,478 & 4,967 \\
\hline \multirow[t]{2}{*}{ - Non-controlling Interest } & 423 & 455 & 1,119 & 1,168 \\
\hline & 1,379 & 1,775 & 3,597 & 6,135 \\
\hline
\end{tabular}

Earning per share for profit attitloutable to the equily

holders of the Compary ouring the period

Earnings Per Share - Basic

$1.58 \quad 2.19 \quad$\begin{tabular}{l}
$4.10 \quad 8.22$ \\
\hline
\end{tabular} 


\section{Appendix 2}

\begin{tabular}{|c|c|c|c|c|}
\hline & 2011 & 2010 & 2011 & 2010 \\
\hline & $\begin{array}{c}\text { CURRENT } \\
\text { Qtr ended } \\
30-S e p \\
\text { (RM 'OOO) }\end{array}$ & $\begin{array}{c}\text { Comparative } \\
\text { atr ended } \\
\text { 30-Sep } \\
\text { (RM 'ODO) }\end{array}$ & $\begin{array}{l}9 \text { Nonth } \\
\text { Cumulative } \\
\text { to-date } \\
\text { (RM ODO) }\end{array}$ & $\begin{array}{l}9 \text { Month } \\
\text { Cumulatlve } \\
\text { to-date } \\
\text { (RM OOD) }\end{array}$ \\
\hline Revenue & 69,811 & 73,970 & 186,404 & 213,313 \\
\hline Operating expenses & $(62,936)$ & $(69,498)$ & $(171,823)$ & $(201,284)$ \\
\hline Depreciation & $(1,079)$ & (872) & $(3,141)$ & $(2,713)$ \\
\hline Other operating income & 348 & 384 & 1,038 & 1,202 \\
\hline Profit from operations & 6,144 & 3,984 & 12,478 & 10,518 \\
\hline Finance costs & (1) & (22) & (20) & (209) \\
\hline Pront before tax & 6,143 & 3,962 & 12,458 & 10,309 \\
\hline Taxation & $(1,843)$ & $(1,188)$ & $(3,737)$ & $(3,092)$ \\
\hline Profit after tax & 4,300 & 2,774 & 8,721 & 7,217 \\
\hline Other Comprehensive Income & - & $\therefore$ & - & - \\
\hline Total Comprehenslve Income & 4,300 & 2,774 & 8,721 & 7,217 \\
\hline \multicolumn{5}{|c|}{ Profit and Total Comprehensive Income } \\
\hline - Equlty holders of the Company & 2,930 & 2,340 & 7,351 & 6,076 \\
\hline - Non-controlling Interest & $\frac{1,370}{4,300}$ & $\begin{array}{r}434 \\
2,774 \\
\end{array}$ & $\begin{array}{l}1,370 \\
8,721\end{array}$ & $\begin{array}{l}1,141 \\
7,217\end{array}$ \\
\hline \multicolumn{5}{|c|}{$\begin{array}{l}\text { Earning per share for profit attributable to the equity } \\
\text { holders of the Company during the period }\end{array}$} \\
\hline Eamings Per Share - Basic & 4.85 & 3.87 & 12.17 & 10.06 \\
\hline
\end{tabular}

